\title{
Cardiovascular surrogate markers and cardiometabolic therapeutics: a viewpoint learned from clinical trials on dipeptidyl peptidase-4 inhibitors
}

\author{
Atsushi Tanaka* (1) and Koichi Node
}

\begin{abstract}
Clinical trials are often performed to investigate the effects of various types of cardiometabolic therapies on cardiovascular surrogate markers, including vascular function and biomarkers. This study platform has the potential to provide information on the suspected actions of drugs and mechanistic insights into their prognostic impact. However, despite using the same class of drugs and similar study designs we are often faced with inconsistent and even conflicting results, possibly leading to some confusion in the clinical setting. When interpreting these results, it is important to investigate what caused the differences and carefully assess the information, taking into account the research situation and the patient population investigated. Using this approach, assessment of the impact on cardiovascular surrogate markers observed in clinical studies from multiple perspectives should help to better understand the potential cardiovascular effects. In this commentary we discuss how we should interpret the effects of cardiometabolic therapeutics on vascular surrogate markers, based on viewpoints learned from the results of clinical trials on dipeptidyl peptidase-4 inhibitors. This learning strategy could also be helpful for appropriate selection of drugs for evidence-based, patient-centric, tailored medication.
\end{abstract}

Keywords: Surrogate marker, Vascular function, Vascular failure, Dipeptidyl peptidase-4 inhibitor

\section{Introduction}

Obesity and metabolic disturbances, such as insulin resistance and hyperinsulinemia, are fundamentally associated with the development of vascular failure and atherosclerosis [1]. The metabolic syndrome is therefore a major cause of atherosclerotic cardiovascular disease (ASCVD). The vascular abnormalities associated with impaired glucose metabolism are characterized by an imbalance between vasodilation and vasoconstriction, increased arterial stiffness, activation of atherogenic and pro-thrombotic responses, and abnormal arterial wall

*Correspondence: tanakaa2@cc.saga-u.ac.jp

Department of Cardiovascular Medicine, Saga University, 5-1-1

Nabeshima, Saga 849-8501, Japan remodeling caused by complicated pathophysiological responses such as excess inflammation, activated sympathetic nerves, and proliferation of vascular smooth muscle cells $[2,3]$. As a consequence, diabetes accelerates the progression of vascular failure, conferring a doubling in risk for ASCVD, independent from other conventional risk factors [4].

Whether or not diabetes treatment reduces the incidence of ASCVD has been studied extensively over a long period of time [1,5-10]. In the last decade, several newer glucose-lowering agents have been tested in large-scale cardiovascular outcome trials (CVOT) to evaluate their cardiovascular safety, prior to commercial distribution [11]. Those clinical trials provided considerable information on the clinical safety and efficacy of each agent, findings that have had a major influence on relevant 
clinical guidelines and recommendations for daily clinical practice. On the other hand, consistent results have not always been observed within each class of agent and the anticipated cardiovascular benefits estimated from basic research were not always seen in CVOTs. These results indicate the presence of cardiovascular effects in specific patient population studies, but no common or specific effects on cardiovascular function and structure. To better understand these profound cardiovascular effects and further explore the underlying mechanisms which explain the cardiovascular results seen in CVOTs, researchers have examined the findings of clinical trials in greater detail and assessed the impact of agents on various types of cardiovascular surrogate markers (Fig. 1). However, despite using the same class of drugs and similar study designs, the results of the studies are often inconsistent and even conflicting, possibly causing some confusion in daily clinical practice. Based on our previous studies and those of other researchers on the glucose-lowering class of drug, dipeptidyl dipeptidase-4 (DPP-4) inhibitors, this paper discusses the clinical significance and use of cardiovascular surrogate markers to examine the specific cardiovascular effects of cardiometabolic therapies.

\section{DPP-4 inhibitors and CVOTs}

DPP-4 inhibitors are a class of glucose-lowering agents that increase insulin secretion in a blood glucosedependent manner by increasing the concentration of incretin hormones, such as glucagon-like peptide-1 and glucose-dependent insulinotropic polypeptide. Due to their safe and effective action on glycemic control, DPP-4 inhibitors are now the most frequently prescribed agent in Asian patients with type 2 diabetes (T2D). To date, five CVOTs on DPP-4 inhibitors have reported a comparison of placebo and glimepiride. A pooled meta-analysis of these trials showed a neutral effect on combined major adverse cardiovascular events and their individual components including ASCVD and mortality [12, 13]. Although the enrolled patient population and observation period were different between the five trials, the primary endpoint of assessing non-inferior safety to placebo was met, while the level of safety required by the authorities was achieved. These findings were the main reason for establishing the position of DPP-4 inhibitors in the current market. Meanwhile, real-world data from Korea demonstrated that there may be some differences between DPP-4 inhibitors in terms of the risk of cardiovascular events [14].






\section{Vascular effects of DPP-4 inhibitors}

Due to the design of these CVOTs no information regarding the specific effects on cardiovascular systems was obtained, despite previous studies on DPP-4 inhibitors showing that treatment did not reduce the incidence of ASCVD. However, previous experimental studies demonstrated that DPP-4 inhibitors have anti-atherosclerotic effects [15-18]. To verify these vascular effects in clinical settings, several clinical studies using cardiovascular surrogate markers have been carried out. In this section, we review the clinical studies that have investigated the effect of DPP-4 inhibitors on representative atherosclerotic and vascular functional markers.

Carotid intima-media thickness (IMT) is an independent predictor of ASCVD and acts as a surrogate marker for the degree of progression of systemic arteriosclerosis. Accordingly, it is used widely in clinical settings and is a simple procedure with high reproducibility [19-21]. For example, the measurement is often used in clinical studies to judge therapeutic effects after intervention. We performed a clinical study (PROLOGUE study) to assess the effect of 24 months of sitagliptin treatment on carotid IMT [22]. A total of 463 patients with T2D were randomized equally into sitagliptin or non-DPP-4 inhibitor groups (conventional treatment group), followed by an observation period of 24 months. The primary endpoint of the PROLOGUE study was the change in mean common carotid artery (CCA) IMT 24 months after randomization. Patient backgrounds at the time of study enrollment were matched in both treatment groups, with a mean age of 70 years, $\mathrm{HbA} 1 \mathrm{c}$ of approximately $7 \%$, and a history of ASCVD in approximately $50 \%$ of the patients. Although sitagliptin tended to suppress the progression of IMT in the PROLOGUE study, there was no significant difference between the two groups in the magnitude of change in mean CCA IMT, despite the safe and efficient hypoglycemic effect of sitagliptin treatment. Other researchers also investigated whether DPP-4 inhibitors attenuated carotid IMT progression in patients with T2D, a background that differed from that of the patients in the PROLOGUE study. The SPEAD-A study showed that 24 months of alogliptin treatment attenuated carotid IMT progression in patients with T2D without a history of ASCVD [23]. The SPIKE study also found that 24 months of sitagliptin treatment attenuated carotid IMT progression in patients with insulin-treated T2D without a history of ASCVD [24].

The results of the primary endpoint were therefore different between our study and these other investigations. We suspect that the different results were due to the different backgrounds of the patients recruited. First, in the PROLOGUE study, HbA1c at the start of treatment was numerically lower than in the other studies, while the target level of HbA1c during the study period was set at $6.2 \%$, allowing aggressive addition of therapeutic agents in both groups. In fact, in the PROLOGUE study some glucose-lowering agents, such as pioglitazone and metformin which suppress the progression of IMT $[25,26]$, were also administered more frequently in the conventional treatment group. This suggests that addition of some glucose-lowering agents may have masked the effect of sitagliptin on carotid IMT in that study [27]. In addition, the fact that statins had already been introduced at enrollment in subjects in the PROLOGUE study at a frequency of 1.5 to 2 times that used in other studies also contributed to difficulty detecting the effect of sitagliptin. Furthermore, two other studies included patients with no history of ASCVD, whereas about half of the patients in the PROLOGUE trials had a history of ASCVD. We then conducted a subgroup analysis of the primary and secondary prevention groups. We found that sitagliptin treatment partially delayed the progression of carotid IMT in the primary prevention group but did not affect progression in the secondary prevention group [28]. Given these findings, the carotid IMT progression inhibitory effect of DPP-4 inhibitors was more apparent in the primary prevention group, where the progression of arteriosclerosis itself was not considered to be very strong. In contrast, it was speculated that the treatment may have been less effective in the secondary prevention group who possibly had advanced atherosclerosis and even ASCVD. These findings emphasize the importance of early therapeutic intervention before the onset of cardiovascular disease in patients with T2D.

A number of experimental studies have demonstrated that DPP-4 inhibitors improve vascular endothelial function through several molecular and signaling pathways [16, 29-40]. Accordingly, physiological vascular functional tests are also often used to detect vascular failure and monitor therapeutic effects in both daily clinical practice and clinical studies [41]. The PROLOGUE study measured brachial-ankle pulse wave velocity (baPWV) as an index of arterial stiffness and flow-mediated dilation (FMD) as a marker of endothelial function. Overall, there was no significant difference in baPWV levels between the two treatment groups, but interestingly, baPWV decreased over time in patients whose HbA1c was $<7 \%$ during the study period, but not in patients whose HbA1c was $>7 \%$ [42]. In another substudy of the PROLOGUE study on FMD, 24 months of sitagliptin treatment did not affect endothelial function [43].

Other researchers have also investigated the effect of DPP-4 inhibitors on endothelial function in various clinical settings and study designs (Table 1). Although a detailed review of these studies is outside the scope of this paper, they appear to show inconsistent and even 
Table 1 Comparison of clinical studies that have investigated the effect of DPP-4 inhibitors on endothelial function

\begin{tabular}{|c|c|c|c|c|c|}
\hline DPP-4 inhibitor & Comparator & Observation period & Population & Result & Citation \\
\hline Sitagliptin & None & 12 weeks & $\mathrm{T} 2 \mathrm{D}$ & Improved FMD & $\begin{array}{l}\text { Kubota Y, et al. } \\
\text { J Korean Med Sci. } 2012\end{array}$ \\
\hline Sitagliptin & Voglibose & 6 weeks & T2D (men) & Decreased FMD & $\begin{array}{l}\text { Ayaori M, et al. } \\
\text { J Am Heart Assoc. } 2013\end{array}$ \\
\hline Alogliptin & (cross-over) & Post-prandial $8 \mathrm{~h}$ & Healthy volunteers & Improved FMD & $\begin{array}{l}\text { Noda Y, et al. } \\
\text { Cardiovasc Diabetol. } 2013\end{array}$ \\
\hline Sitagliptin & Conventional therapy & 6 months & $\begin{array}{l}\text { Uncontrolled T2D and } \\
\text { CAD }\end{array}$ & Improved RHI & $\begin{array}{l}\text { Matsubara J, et al. } \\
\text { Circ J. } 2013\end{array}$ \\
\hline Sitagliptin & Placebo & 12 weeks & $\begin{array}{l}\text { Newly diagnosed IGT or } \\
\text { T2D with ACS }\end{array}$ & No change in $\mathrm{RHI}$ & $\begin{array}{l}\text { Hage C, et al. } \\
\text { Diab Vasc Dis Res. } 2014\end{array}$ \\
\hline Sitagliptin & Voglivose & 12 weeks & Uncontrolled T2D & Improved FMD & $\begin{array}{l}\text { Nakamura K, et al. } \\
\text { Cardiovasc Diabetol. } 2014\end{array}$ \\
\hline Teneligliptin & None & 3 months & $\mathrm{T} 2 \mathrm{D}$ & Improved FMD & $\begin{array}{l}\text { Hashikata T, et al. } \\
\text { Heart Vessels. } 2016\end{array}$ \\
\hline Trelagliptin & None & 12 weeks & $\mathrm{T} 2 \mathrm{D}$ & No change in FMD & $\begin{array}{l}\text { Ida S, et al. } \\
\text { Cardiovasc Diabetol. } 2016\end{array}$ \\
\hline Sitagliptin & Conventional therapy & 24 months & $\mathrm{T} 2 \mathrm{D}$ & No change in FMD & $\begin{array}{l}\text { Maruhashi T, et al. } \\
\text { Cardiovasc Diabetol. } 2016\end{array}$ \\
\hline Not specific & Conventional therapy & 12 months & $\mathrm{T} 2 \mathrm{D}$ & Improved FMD & $\begin{array}{l}\text { Leung M, et al. } \\
\text { Diab Vasc Dis Res. } 2016\end{array}$ \\
\hline Linagliptin & Placebo & 12 weeks & $\mathrm{T} 2 \mathrm{D}$ & FMD tended to improve & $\begin{array}{l}\text { Baltzis D, et al. } \\
\text { J Clin Endocrinol Metab. } \\
2016\end{array}$ \\
\hline Linagliptin & Placebo & 4 weeks & $\mathrm{T} 2 \mathrm{D}$ & $\begin{array}{l}\text { Improved renal endothe- } \\
\text { lial function }\end{array}$ & $\begin{array}{l}\text { Ott C, et al. } \\
\text { Diabetologia. } 2016\end{array}$ \\
\hline Linagliptin & Glimepiride & 4 weeks & T2D (no history of ASCVD) & No change in FMD & $\begin{array}{l}\text { Jax T, et al. } \\
\text { Cardiovasc Diabetol. } 2017\end{array}$ \\
\hline Saxagliptin & Metformin & 12 weeks & Newly diagnosed T2D & Improved FMD & $\begin{array}{l}\text { Li F, et al. } \\
\text { Exp Clin Endocrinol Diabe- } \\
\text { tes. } 2017\end{array}$ \\
\hline Linagliptin & Metformin & 16 weeks & Uncontrolled T2D & Improved FMD & $\begin{array}{l}\text { Shigiyama F, et al. } \\
\text { J Diabetes Investig. } 2017\end{array}$ \\
\hline Vildagliptin & Metformin & 12 weeks & $\mathrm{T} 2 \mathrm{D}$ & No change in FMD & $\begin{array}{l}\text { Kitao N, et al. } \\
\text { Cardiovasc Diabetol. } 2017\end{array}$ \\
\hline Saxagliptin & Metformin & 12 months & $\mathrm{T} 2 \mathrm{D}$ & Improved FMD & $\begin{array}{l}\text { Dell'Oro R, et al. } \\
\text { High Blood Press Cardiovasc } \\
\text { Prev. } 2017\end{array}$ \\
\hline Linagliptin & Voglibose & 12 weeks & $\begin{array}{l}\text { Untreated and early stage } \\
\text { T2D }\end{array}$ & Improved $\mathrm{RHI}$ & $\begin{array}{l}\text { Koyama T, et al. } \\
\text { Heart Vessels. } 2018\end{array}$ \\
\hline Linagliptin & Placebo & 12 weeks & $\mathrm{T} 2 \mathrm{D}$ and $\mathrm{CAD}$ & No change in FMD & $\begin{array}{l}\text { Tripolt NJ, et al. } \\
\text { Cardiovasc Diabetol. } 2018\end{array}$ \\
\hline Saxagliptin & None & 3 months & $\mathrm{T} 2 \mathrm{D}$ & Improved FMD & $\begin{array}{l}\text { Kajikawa M, et al. } \\
\text { Sci Rep. } 2019\end{array}$ \\
\hline Vildagliptin & Glibenclamide & 12 weeks & $\begin{array}{l}\text { T2D and HT without } \\
\text { ASCVD }\end{array}$ & No change in $\mathrm{RHI}$ & $\begin{array}{l}\text { Cosenso-Martin LN, et al. } \\
\text { Diabetes Metab Syndr Obes. } \\
2020\end{array}$ \\
\hline
\end{tabular}

ACS: acute coronary syndrome; ASCVD: atherosclerotic cardiovascular disease; CAD: coronary artery disease; FMD: flow-mediated dilation; HT: hypertension; IGT: impaired glucose tolerance; $\mathrm{RHI}$ : reactive hyperemia index; T2D: type 2 diabetes

confounding results. Almost all the studies included patients with T2D; however, the detailed medical background of the patients differed between studies to a greater or lesser extent. No study had exactly the same design or target population, suggesting that each result only indicated the potential impact of the research situation for the DPP-4 inhibitor tested and/ or the patient population investigated. In addition, whether or not the results can be applied to other research and clinical situations and patient populations is a major limitation and another scientific matter for consideration. 


\section{Clinical perspectives}

Clinical studies often use surrogate markers to easily estimate the cardiovascular effects of the drug tested. However, when interpreting the results obtained from such studies it is important to carefully assess the information, taking into account the research situation and the patient population examined. As an example, when assessing the vascular effects of glucose-lowering agents in T2D, it is essential to recognize that the effects observed may often be affected by a number of factors (Fig. 2). If a drug shows a consistent impact on surrogate markers in almost all studies carried out under different situations and/or patient populations, then that impact would be universally expected in a broad range of clinical settings. In contrast, when we are faced with inconsistent or even conflicting impacts on cardiovascular surrogate markers or even differences in the results of CVOTs, it is critical to investigate what caused these differences. This approach can help physicians to predict possible actions and effects of the drug on cardiovascular properties and vascular function in individual patients. Furthermore, because recent clinical studies have reported substantial differences in the risk of atrial fibrillation between classes of glucose-lowering agents [44, 45], further research is also needed to establish potential or suitable surrogate markers of atrial fibrillation and then examine the effect of each drug on these markers. Such approach will result in the optimum selection of drugs and evidence-based patient-centric medication for cardiovascular protection [46].

\section{Conclusion}

The results of large-scale CVOTs and even individual clinical studies have been obtained under very limited conditions for specific endpoints and do not necessarily represent the entire potential of the drug. It is also difficult to make a direct comparison of studies conducted under different conditions and patient populations. Therefore, it is reasonable to consider that a result may show only one aspect of an individual research situation and/or specific patient population. Assessment of the impact on cardiovascular surrogate markers observed in clinical studies from multiple perspectives should help to better understand the potential cardiovascular effects and lead to more appropriate selection of drugs for tailored medication.

\section{Acknowledgements}

The authors would like to thank the study participants, staff, and investigators of the PROLOGUE study. We also thank Ms. Aya Yamada for her assistance. This work was supported partly by the Uehara Memorial Foundation.

\section{Authors' contributions}

AT wrote the draft of the article, which was then critically reviewed by KN. Both authors approved the final version of manuscript.

\section{Funding}

None

Availability of data and materials

Not applicable.

Ethics approval and consent to participate

Not applicable.

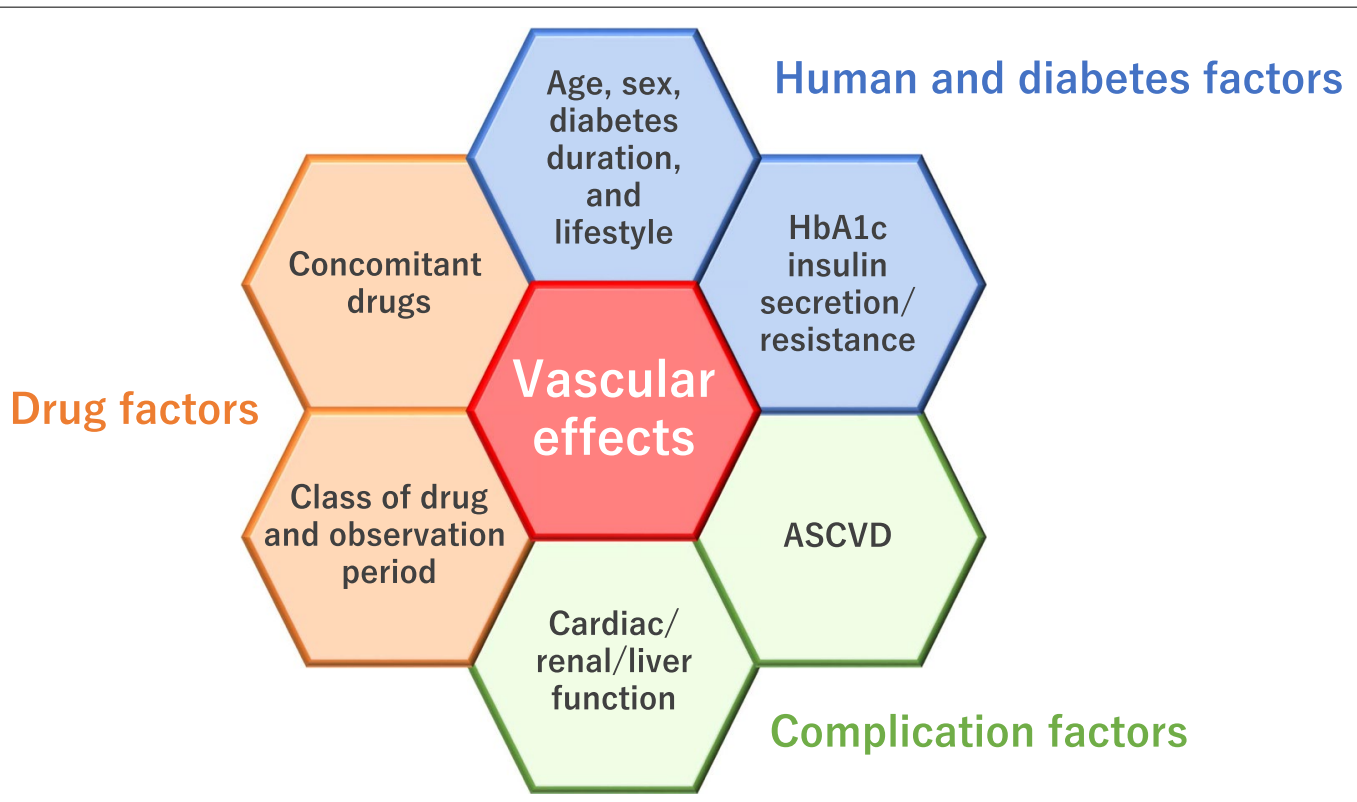

Fig. 2 Multifaceted interaction of relevant factors and resultant vascular effect 


\section{Consent for publication \\ Not applicable.}

\section{Competing interests}

AT received honoraria from Boehringer Ingelheim and research funding from GlaxoSmithKline. KN has received research grants from Asahi Kasei, Astellas, Bayer, Boehringer Ingelheim, Mitsubishi Tanabe, Teijin, and Terumo, scholarships from Astellas, Bayer, Bristol-Myers Squibb, Daiichi Sankyo, Daiichi Sankyo Healthcare, Takeda, and Teijin, and personal fees from Astellas, AstraZeneca, Bayer, Boehringer Ingelheim, Daiichi Sankyo Healthcare, Eli Lilly, Kowa, Mitsubishi Tanabe, MSD, Novartis, Ono, Takeda, and Teijin.

Received: 20 January 2021 Accepted: 30 January 2021

Published online: 11 February 2021

\section{References}

1. Ray KK, Seshasai SR, Wijesuriya S, Sivakumaran R, Nethercott S, Preiss D, Erqou S, Sattar N. Effect of intensive control of glucose on cardiovascular outcomes and death in patients with diabetes mellitus: a meta-analysis of randomised controlled trials. Lancet. 2009;373(9677):1765-72.

2. Paneni F, Beckman JA, Creager MA, Cosentino F. Diabetes and vascular disease: pathophysiology, clinical consequences, and medical therapy: part I. Eur Heart J. 2013;34(31):2436-43.

3. Paneni F, Costantino S, Cosentino F. Insulin resistance, diabetes, and cardiovascular risk. Curr atheroscler Rep. 2014;16(7):419.

4. Sarwar N, Gao P, Seshasai SR, Gobin R, Kaptoge S, Di Angelantonio E, Ingelsson E, Lawlor DA, Selvin E, Stampfer M, et al. Diabetes mellitus, fasting blood glucose concentration, and risk of vascular disease: a collaborative meta-analysis of 102 prospective studies. Lancet. 2010;375(9733):2215-22.

5. UK Prospective Diabetes Study (UKPDS) Group. Effect of intensive bloodglucose control with metformin on complications in overweight patients with type 2 diabetes (UKPDS 34). Lancet. 1998;352(9131):854-65.

6. Gaede $\mathrm{P}$, Lund-Andersen $\mathrm{H}$, Parving $\mathrm{HH}$, Pedersen O. Effect of a multifactorial intervention on mortality in type 2 diabetes. N Engl J Med. 2008;358(6):580-91.

7. Gerstein HC, Miller ME, Byington RP, Goff DC Jr, Bigger JT, Buse JB, Cushman WC, Genuth S, Ismail-Beigi F, Grimm RH Jr, et al. Effects of intensive glucose lowering in type 2 diabetes. N Engl J Med. 2008;358(24):2545-59.

8. Holman RR, Paul SK, Bethel MA, Matthews DR, Neil HA. 10-year followup of intensive glucose control in type 2 diabetes. N Engl J Med. 2008;359(15):1577-89

9. Patel A, MacMahon S, Chalmers J, Neal B, Billot L, Woodward M, Marre M, Cooper M, Glasziou P, Grobbee D, et al. Intensive blood glucose control and vascular outcomes in patients with type 2 diabetes. N Engl J Med. 2008;358(24):2560-72.

10. Hill D, Fisher M. The effect of intensive glycaemic control on cardiovascular outcomes. Diabetes Obes Metab. 2010;12(8):641-7.

11. Cefalu WT, Kaul S, Gerstein HC, Holman RR, Zinman B, Skyler JS, Green JB, Buse JB, Inzucchi SE, Leiter LA, et al. Cardiovascular outcomes trials in type 2 diabetes: where do we go from here? Reflections from a diabetes care editors' expert forum. Diabetes Care. 2018:41(1):14-31.

12. Fei $Y$, Tsoi MF, Cheung BMY. Cardiovascular outcomes in trials of new antidiabetic drug classes: a network meta-analysis. Cardiovasc Diabetol. 2019;18(1):112.

13. Sinha B, Ghosal S. Meta-analyses of the effects of DPP-4 inhibitors, SGLT2 inhibitors and GLP1 receptor analogues on cardiovascular death, myocardial infarction, stroke and hospitalization for heart failure. Diabetes Res Clin Pract. 2019;150:8-16.

14. Ha KH, Kim B, Shin HS, Lee J, Choi H, Kim HC, Kim DJ. Comparative cardiovascular risks of dipeptidyl peptidase-4 inhibitors: analyses of real-world data in Korea. Korean Circ J. 2018;48(5):395-405.

15. Shah Z, Kampfrath T, Deiuliis JA, Zhong J, Pineda C, Ying Z, Xu X, Lu B, Moffatt-Bruce S, Durairaj R, et al. Long-term dipeptidyl-peptidase 4 inhibition reduces atherosclerosis and inflammation via effects on monocyte recruitment and chemotaxis. Circulation. 2011;124(21):2338-49.

16. Matsubara J, Sugiyama S, Sugamura K, Nakamura T, Fujiwara Y, Akiyama E, Kurokawa H, Nozaki T, Ohba K, Konishi M, et al. A dipeptidyl peptidase-4 inhibitor, des-fluoro-sitagliptin, improves endothelial function and reduces atherosclerotic lesion formation in apolipoprotein E-deficient mice. J Am Coll Cardiol. 2012;59(3):265-76.

17. Ta NN, Schuyler CA, Li Y, Lopes-Virella MF, Huang Y. DPP-4 (CD26) inhibitor alogliptin inhibits atherosclerosis in diabetic apolipoprotein E-deficient mice. J Cardiovasc Pharmacol. 2011;58(2):157-66.

18. Akita K, Isoda K, Shimada K, Daida H. Dipeptidyl-peptidase-4 inhibitor, alogliptin, attenuates arterial inflammation and neointimal formation after injury in low-density lipoprotein (LDL) receptor-deficient mice. J Am Heart Assoc. 2015;4(3):e001469.

19. Bots ML. Carotid intima-media thickness as a surrogate marker for cardiovascular disease in intervention studies. Curr Med Res Opin. 2006:22(11):2181-90.

20. Lorenz MW, Gao L, Ziegelbauer K, Norata GD, Empana JP, Schmidtmann I, Lin HJ, McLachlan S, Bokemark L, Ronkainen K, et al. Predictive value for cardiovascular events of common carotid intima media thickness and its rate of change in individuals at high cardiovascular risk-results from the PROG-IMT collaboration. PLOS ONE. 2018;13(4):e0191172.

21. Willeit P, Tschiderer L, Allara E, Reuber K, Seekircher L, Gao L, Liao X, Lonn E, Gerstein HC, Yusuf S, et al. Carotid intima-media thickness progression as surrogate marker for cardiovascular risk: meta-analysis of 119 clinical trials involving 100667 patients. Circulation. 2020;142(7):621-42.

22. Oyama J, Murohara T, Kitakaze M, Ishizu T, Sato Y, Kitagawa K, Kamiya H, Ajioka M, Ishihara M, Dai K, et al. The effect of sitagliptin on carotid artery atherosclerosis in type 2 diabetes: the PROLOGUE randomized controlled trial. PLoS Med. 2016;13(6):e1002051.

23. Mita T, Katakami N, Yoshii H, Onuma T, Kaneto H, Osonoi T, Shiraiwa T, Kosugi K, Umayahara Y, Yamamoto T, et al. Alogliptin, a dipeptidyl peptidase 4 inhibitor, prevents the progression of carotid atherosclerosis in patients with type 2 diabetes: the study of preventive effects of alogliptin on diabetic atherosclerosis (SPEAD-A). Diabetes Care. 2016;39(1):139-48.

24. Mita T, Katakami N, Shiraiwa T, Yoshii H, Onuma T, Kuribayashi N, Osonoi T, Kaneto H, Kosugi K, Umayahara Y, et al. Sitagliptin attenuates the progression of carotid intima-media thickening in insulin-treated patients with type 2 diabetes: the sitagliptin preventive study of intima-media thickness evaluation (SPIKE): a randomized controlled trial. Diabetes Care. 2016;39(3):455-64.

25. Katakami N, Yamasaki Y, Hayaishi-Okano R, Ohtoshi K, Kaneto H, Matsuhisa M, Kosugi K, Hori M. Metformin or gliclazide, rather than glibenclamide, attenuate progression of carotid intima-media thickness in subjects with type 2 diabetes. Diabetologia. 2004;47(11):1906-13.

26. Mazzone T, Meyer PM, Feinstein SB, Davidson MH, Kondos GT, D’Agostino RB Sr, Perez A, Provost JC, Haffner SM. Effect of pioglitazone compared with glimepiride on carotid intima-media thickness in type 2 diabetes: a randomized trial. JAMA. 2006;296(21):2572-81.

27. Tanaka A, Kawaguchi A, Oyama Jl, Ishizu T, Ito H, Fukui J, Kondo T, Kuroki S, Nanasato M, Higashi Y, et al. Differential effect of concomitant antidiabetic agents on carotid atherosclerosis: a subgroup analysis of the PROLOGUE study. Heart Vessels. 2019;34(2):375-84.

28. Tanaka A, Yoshida H, Nanasato M, Oyama Jl, Ishizu T, Ajioka M, Ishiki R, Saito M, Shibata Y, Kaku K, et al. Sitagliptin on carotid intima-media thickness in type 2 diabetes patients receiving primary or secondary prevention of cardiovascular disease: a subgroup analysis of the PROLOGUE study. Int J Cardiol. 2018;271:331-5.

29. Woodman OL, Ortega JM, Hart JL, Klein T, Potocnik S. Influence of type-4 dipeptidyl peptidase inhibition on endothelium-dependent relaxation of aortae from a $\mathrm{db} / \mathrm{db}$ mouse model of type 2 diabetes: a comparison with the effect of glimepiride. Diabetes Metab Syndr Obes. 2019;12:1449-58.

30. Vellecco V, Mitidieri E, Gargiulo A, Brancaleone V, Matassa D, Klein T, Esposito F, Cirino G, Bucci M. Vascular effects of linagliptin in non-obese diabetic mice are glucose-independent and involve positive modulation of the endothelial nitric oxide synthase (eNOS)/caveolin-1 (CAV-1) pathway. Diabetes Obes Metab. 2016;18(12):1236-43.

31. Ma S, Bai Z, Wu H, Wang W. The DPP-4 inhibitor saxagliptin ameliorates Ox-LDL-induced endothelial dysfunction by regulating AP-1 and NF-KB. Eur J Pharmacol. 2019;851:186-93.

32. Nakagami H, Pang Z, Shimosato T, Moritani T, Kurinami $H$, Koriyama $H$, Tenma A, Shimamura M, Morishita R. The dipeptidyl peptidase-4 inhibitor teneligliptin improved endothelial dysfunction and insulin resistance in the SHR/NDmcr-cp rat model of metabolic syndrome. Hypertens Res. 2014;37(7):629-35. 
33. Liu L, Liu J, Wong WT, Tian XY, Lau CW, Wang YX, Xu G, Pu Y, Zhu Z, Xu A, et al. Dipeptidyl peptidase 4 inhibitor sitagliptin protects endothelial function in hypertension through a glucagon-like peptide 1-dependent mechanism. Hypertension. 2012;60(3):833-41.

34. Aini K, Fukuda D, Tanaka K, Higashikuni Y, Hirata Y, Yagi S, Kusunose K, Yamada H, Soeki T, Sata M. Vildagliptin, a DPP-4 Inhibitor, Attenuates Endothelial Dysfunction and Atherogenesis in Nondiabetic Apolipoprotein E-Deficient Mice. Int Heart J. 2019;60(6):1421-9.

35. Ishii M, Shibata R, Kondo K, Kambara T, Shimizu Y, Tanigawa T, Bando YK, Nishimura M, Ouchi N, Murohara T. Vildagliptin stimulates endothelial cell network formation and ischemia-induced revascularization via an endothelial nitric-oxide synthase-dependent mechanism. J Biol Chem. 2014;289(39):27235-45.

36. Wang H, Zhou Y, Guo Z, Dong Y, Xu J, Huang H, Liu H, Wang W. Sitagliptin attenuates endothelial dysfunction of Zucker diabetic fatty rats: implication of the antiperoxynitrite and autophagy. J Cardiovasc Pharmacol Ther. 2018;23(1):66-78.

37. Jiang $T$, Jiang $D$, Zhang $L$, Ding $M$, Zhou $H$. Anagliptin ameliorates high glucose- induced endothelial dysfunction via suppression of NLRP3 inflammasome activation mediated by SIRT1. Mol Immunol. 2019;107:54-60

38. Salheen SM, Panchapakesan U, Pollock CA, Woodman OL. The dipeptidyl peptidase-4 inhibitor linagliptin preserves endothelial function in mesenteric arteries from type 1 diabetic rats without decreasing plasma glucose. PLoS ONE. 2015;10(11):e0143941.

39. Solini A, Rossi C, Duranti E, Taddei S, Natali A, Virdis A. Saxagliptin prevents vascular remodeling and oxidative stress in $\mathrm{db} / \mathrm{db}$ mice. Role of endothelial nitric oxide synthase uncoupling and cyclooxygenase. Vascul Pharmacol. 2016;76:62-71.

40. Zhu B, Li Y, Mei W, He M, Ding Y, Meng B, Zhao H, Xiang G. Alogliptin improves endothelial function by promoting autophagy in perivascular adipose tissue of obese mice through a GLP-1-dependent mechanism. Vasc Pharmacol. 2019;115:55-63.

41. Tanaka A, Tomiyama H, Maruhashi T, Matsuzawa Y, Miyoshi T, Kabutoya T, Kario K, Sugiyama S, Munakata M, Ito H, et al. Physiological diagnostic criteria for vascular failure. Hypertension. 2018;72(5):1060-71.

42. Tomiyama H, Miwa T, Kan K, Matsuhisa M, Kamiya H, Nanasato M, Kitano T, Sano H, Ohno J, lida M, et al. Impact of glycemic control with sitagliptin on the 2-year progression of arterial stiffness: a sub-analysis of the PROLOGUE study. Cardiovasc Diabetol. 2016;15(1):150.

43. Maruhashi T, Higashi Y, Kihara Y, Yamada H, Sata M, Ueda S, Odawara M, Terauchi Y, Dai K, Ohno J, et al. Long-term effect of sitagliptin on endothelial function in type 2 diabetes: a sub-analysis of the PROLOGUE study. Cardiovasc Diabetol. 2016;15(1):134.

44. Liou YS, Yang FY, Chen HY, Jong GP. Antihyperglycemic drugs use and new-onset atrial fibrillation: a population-based nested case control study. PLoS ONE. 2018;13(8):e0197245.

45. Ling AW, Chan CC, Chen SW, Kao YW, Huang CY, Chan YH, Chu PH. The risk of new-onset atrial fibrillation in patients with type 2 diabetes mellitus treated with sodium glucose cotransporter 2 inhibitors versus dipeptidyl peptidase-4 inhibitors. Cardiovasc Diabetol. 2020;19(1):188

46. Tanaka A, Node K. Evidence-based and tailored medication in type 2 diabetes: a pathway learned from clinical trials. Cardiovasc Diabetol. 2019;18(1):19.

\section{Publisher's Note}

Springer Nature remains neutral with regard to jurisdictional claims in published maps and institutional affiliations.
Ready to submit your research? Choose BMC and benefit from:

- fast, convenient online submission

- thorough peer review by experienced researchers in your field

- rapid publication on acceptance

- support for research data, including large and complex data types

- gold Open Access which fosters wider collaboration and increased citations

- maximum visibility for your research: over $100 \mathrm{M}$ website views per year

At BMC, research is always in progress.

Learn more biomedcentral.com/submissions 